\title{
Concerns of European Commission for small and medium size enterprises development
}

\author{
Mircea Muntean, Universitatea Vasile Alecsandri of Bacău
}

\begin{abstract}
:
European Commission initiated development programs for small and medium size enterprises (SMEs) comprised in SBA initiative. The respective programs establish measures in order to facilitate: setting up in a short time span of SMEs, access to finance, as well as the possibility of introducing it both European Single Market and global market processed products and performed services.

A concern of European Commission consisted in recommendation made to Member States that, by means of national programs, will support the SMEs development by offering the possibility of attendance to cross-border transactions with European Single Market.

European Commission's programs were supported by European Council and approved by European Parliament, following that every Member State will establish programs and initiatives on national level.

European Commission's strategy concerning SMEs development is the increase of their number, labour force absorption and a faster economic and financial crisis traversing.
\end{abstract}

\section{Key words:}

European Commission, Europe's Council, SMEs, SBA initiative

SMEs development and creation play an important role in what the future employment, goods production increase, services performing as well as prosperity of European Union is concerned. Therefore the Commission launched in 2008 an initiative called SBA (Small Business Act for Europe), to put SMEs at the forefront of decision-making, to strengthen their potential to create jobs in the EU and to promote their competitiveness both within the Single Market and in the global markets. As a key element, the SBA aims at making the "Think Small First" principle a reality in policies and decision making at all levels in the EU.

The SBA initiative has as main aim the adopting of complete and comprehensive policy measures in favour of SMEs for an easier traversing of economical and financial crisis by European Union's Member States. The measures established through this initiative are comprised in an action plan approved in December 2008 by the Europe's Council and supported by the European Parliament that invited the Member States to implement the SBA in its entirety.

In December 2009, the European Commission drew up the Report concerning the appliance of initiative SBA (COM (2009) 680 final), where the practical use of measures contained in SBA Action Plan and in the European Economic Recovery Plan were presented.

From the rapport study resulted:

- $\quad$ adopting, starting with the 1 of June 2009 of reduced VAT rates. Therefore, the possibility of boosting economic activity notably in labour-intensive services was offer to the Member States.

- the proposal on VAT invoicing, adopted by the European Commission in January 2009, that aims at ensuring equal treatment of paper and electronic 
invoices. The appliance of this proposal is estimated to have a maximum midterm reduction potential of $€ 18.4$ billion if all businesses would send all their invoices electronically.

The implementation of the measures program established by SBA initiative was realized with vary approaches and results according to specific conditions for every member state. Therefore, Belgium launched in 2008 its 'Plan PME', which includes 40 measures covering the main objectives of the SBA initiative. In other countries, such Italy and Ireland, their governments created working groups that take action in the ten areas. In their 2009 National Progress Reports in the context of the Lisbon Partnership for growth and jobs, Finland, France, the Netherlands, Romania and the United Kingdom have explicitly reported on how they are implementing the SBA. The United Kingdom has presented in a very detailed annex the measures taken for each of the ten principles of the SBA. Moreover, some regions, such as Catalonia (Spain) or North Rhine-Westphalia (Germany), have also adopted the SBA.

The evaluation of results obtained from SBA initiative appliance starts from the "Think Small First" principle. Therefore, starting with February 2009 the European Commission proposed to give Member States the possibility to exempt microenterprises from accounting rules. Starting from this recommendation, Member States would be free to devise accounting regimes best suited to their micro-enterprises, aspect that would determine that up to 5.4 million entities will realize expenses savings of $€ 6.3$ billion for the European Union economy.

A main aim of European Commission is reducing the expenses concerning the SMEs administration with $33 \%$, aspect materialized in saving $€ 123.8$ billion for European Union's budget. This aim is comprised in "Action Programme for Reducing Administrative Burdens in the EU: sector Reduction Plan and 2009 Actions" - COM (2009) 544 approved by Europe's Council and Parliament.

Concerns of European Commission are met in simplifying the administrative burdens of SMEs by reducing the average time and cost to start-up a private limited company, to 8 days in 2009 compared to 9 days in 2008 . Also, the cost for setting up a firm is reduced from $€ 463$ in 2008 to $€ 417$ in 2009.

On European Commission proposal, eighteen countries have provided an operational one-stop-shop with the purpose of fastening the creation of private limited companies. In order to achieve it, pre-defined procedures were elaborated concerning: company registration, tax registration, etc. Such examples are:

- Bulgaria has consolidated the SMEs streamlining of start-up procedures in which nine start-up procedures have been merged and simplified into just one;

- Germany has successfully amended the legislation for private limited companies, by simplifying the procedure and by stimulating the creation of new enterprises;

- Hungary, Malta and Slovakia simplified the legislation and contributed to time reduction companies setting up;

- Slovenia created the electronic "one-stop-shop system" that can register all forms of companies in 3 days or less and has resulted in savings of $€ 10.2$ million a year for SMEs.

In what the access to finance is concerned, the Commission has simplified state aid rules for SMEs at the Member States level. Therefore, the General Block Exemption Regulation (GBER) was adopted as part of the SBA initiative, which consolidates into one text and harmonises the rules previously set out in five separate regulations, and enlarges the categories of state aid covered by the exemption. The GBER introduced new rules on aid intensities for SMEs. By new rule 20\% higher aid proportion 
allowed for small enterprises and $10 \%$ higher for medium-sized enterprises as well as on incentives for the creation of start-ups and support for women entrepreneurs. Concerning state aid, we mention that in 2008 the approved amount was $€ 2.8$ billion, an increase of $€ 0.3$ billion compared to 2007.

The Commission also adopted a Handbook on State Aid rules which gives a concise overview of the aid possibilities for SMEs permitted under Community state aid rules. The European Commission's financial support for SMEs also consisted in adopting a temporary framework on state aid for 2009/2010 providing Member States with increased possibilities to tackle the effects of the credit squeeze on the real economy. In particular, Member States are able to grant subsidised loans, loan guarantees at a reduced premium, risk capital for SMEs and direct state aid of up to $€ 500000$ without notification of individual cases.

In 2009 the European Commission took action in partnership with The European Investment Bank (EIB) and The European Investment Fund in order to assure SMEs' access to finance. The European Investment Bank has increased its lending activity dedicated to SMEs around $€ 11.5$ billion in 2009. For the same period, The European Investment Fund gave credits of $€ 1.23$ billion.

The state aids granting were used in some Member states as measure for SMEs supporting and for bearing with reduced consequences of financial and economic crisis. Therefore, most Member States (Austria, Belgium, the Czech Republic, Denmark, Estonia, Finland, France, Germany, Greece, Italy, Lithuania, Luxembourg, the United Kingdom, Spain, the Netherlands and Hungary) have also adopted policy measures to enhance SMEs' access to liquidity, especially to bank lending, through the creation and extension of loan and guarantee schemes for SMEs. The EIB package of $€ 30$ billion for loans to SMEs also allows some member countries to use a second level guarantee scheme. In addition, Belgium and France have set up a "credit mediator" acting as a contact point for SMEs and entrepreneurs that have problems with their bank.

Also as propriety, The Commission has simplified the Cohesion Policy management rules to facilitate the implementation of the 455 Cohesion Policy programmes planned for 2007-2013. These programmes represent a total investment of $€ 347$ billion. Hence, The Commission supported the SMEs access towards investment flows directed particularly towards sectors linked to energy efficiency and the use of renewable energies in housing with the purpose to provide growth and jobs.

The Commission proposed measures for the simplification of the 7th Framework Programme for Research and Technological Development (FP7) in such way that the SMEs taking part in an FP7 project to keep the benefit of SME treatment for that project even if it exceeds the SME ceilings during the duration of the project.

To encourage and stimulate the SMEs activity, The Commission and the Member States jointly decided to further lower the fees for EU-wide trade mark rights by $40 \%$ and to simplify the registration procedure from 1 May 2009. These measures are aimed to stimulate SMEs to realization of cross-border operations and entrance on the Single Market.

In the frame of SBA initiative, the Commission invited Member States to make the most of the "European Code of Best practices" (called "the SME Code") where SMEs access to public procurement contracts and public acquisitions manners are foreseen. In presented rapport, The Commission has also highlighted the importance of a full and timely transposition of the Services Directive, which will significantly facilitate the establishment of businesses and the cross-border provision of services. The fast establishment of new enterprises is realized by means of points of single contact with the purpose of offering to interested persons the possibility of filling in all necessary formalities, such as: authorizations, notifications, environmental licenses, by 
electronic means. Together with Member States, the Commission has devoted significant resources to monitor and coordinate the implementation of the Directive up to 28 December 2009. This activity will continue in the future, based on a project (SPOCs) intended to further enhance the points of single contact beyond 2010.

The action plan established by SBA initiative takes into consideration the creation of SMEs on global level and constitutes one of European Commission's strategies up to 2020 .

\section{Bibliography}

1.Muntean, M., Păcurari, D., Influența integrării în Uniunea Europeană asupra fiscalității din România, Revista Studii şi Cercetări Ştiinţifice - Seria Ştiinţe Economice - a Universităţii din Bacău, nr.13/2008.

2.Muntean, M., Păcurari, D., Preocupări ale Comisiei Europene pentru modernizarea fiscalităţii in ţările membre ale Uniunii Europene privind impozitele indirecte, Revista Finanţe publice şi contabilitate, nr.10/2009.

3. Brezeanu, P., Simion, I, Celea, S., Fiscalitate europeană, Ed.Economică, București 2005.

4.http://ec.europa.eu/enterprise/policies/sme/small-business-

act/implementation/files/sba_imp_ro.pdf 